\section{Drought effects on the floristic differentiation of Greek fir forests in the mountains of central Greece}

\author{
Dimitrios A Samaras ${ }^{(1-2)}$, Stefanie Gaertner ${ }^{(1)}$, Albert Reif ${ }^{(1)}$, \\ Konstantinos Theodoropoulos ${ }^{(2)}$
}

Greek fir (Abies cephalonica Loudon) grows in montane Mediterranean climates characterized by dry, warm summers. Drought is an important climatic feature of these montane ecosystems as it affects the floristic composition, structure and distribution of plant communities. The Oxia-North Vardousia mountain system is one of the few areas in Greece with an extensive, well-preserved Greek fir forest. This study aims at describing the Greek fir forest vegetation of such area and determining the drought-related factors affecting their floristic composition and differentiation. Vegetation relevés were classified and ordinated. The impact of drought-related variables on the vegetation composition was analyzed. A cluster analysis was used to reveal the most important factor for the discrimination of the main plant communities and to determine the drought threshold between them. Two plant communities that reflect the differentiation of the Greek fir forests in central Greece into xerophytic and mesophytic forest communities were described. Each community was divided into two subcommunities. The elevational distribution of Greek fir forests in the mountains of central Greece follows a drought gradient linked to the two main climatic components of drought, precipitation and potential evapotranspiration. The combination of these two drought-related variables into a suitable humidity index was found to adequately differentiate the xerophytic from the mesophytic forest communities and define their drought threshold.

Keywords: Abies Cephalonica, Aridity, Habitat Differentiation, Humidity Index, Plant Communities, Synecology, Syntaxonomy, Sterea Ellas

\section{Introduction}

Fir (Abies spp.) forests are a distinctive, widespread landscape feature with high ecological and economic importance in the mountains of Greece, especially in the southern and central part of the country. They cover an area of 543300 ha $(16.17 \%$ of the total forested area) and comprise $38 \%$ of the coniferous forests of Greece (Albanis et al. 2000). Three closely related fir species occur in Greece, Abies cephalonica Loudon (Greek fir), A. alba Mill. (silver fir) and their natural hybrid A. × borisii-regis Mattf. (Mitsopoulos \& Panetsos 1987, Christensen 1997). The

endemic Greek fir is the dominant forest tree in the mountains of Peloponnisos (southern Greece) and Sterea Ellas (south-central Greece). In the northern mainland, Greek fir is replaced by $A$. $\times$ borisii-regis. The silver fir can only be found in the northernmost parts of the mainland (Christensen 1997). Greek fir is very variable in morphology and often co-occurs with $A$. $\times$ borisii-regis in mixed stands (Künemund 2008). Nevertheless, is very difficult to distinguish between the two species. Recent studies on the genetic variation of Greek fir populations have confirmed that the two species cannot be distin-

(1) Chair of Site Classification and Vegetation Science, Faculty of Environment and Natural Resources, University of Freiburg, D-79085 Freiburg i.Br. (Germany); (2) Laboratory of Forest Botany-Geobotany, Faculty of Forestry and Natural Environment, Aristotle University of Thessaloniki, GR-54124 Thessaloniki (Greece)

@ Dimitrios A Samaras (mail@dimitrios-samaras.net)

Received: Dec 23, 2013 - Accepted: Dec 19, 2014

Citation: Samaras DA, Gaertner S, Reif A, Theodoropoulos K, 2015. Drought effects on the floristic differentiation of Greek fir forests in the mountains of central Greece. iForest 8: 786-797 [online 2015-04-08] URL: http://www.sisef.it/iforest/contents/?id=ifor1214-007

Communicated by: Paola Mairota guished based on isozyme or molecular markers (Fady \& Conkle 1993, Scaltsoyiannes et al. 1999, Drouzas 2000). For the purposes of our study it was considered that all fir trees found in the study area belong to the species A. cephalonica s.l.

The phytosociological research of Greek fir forests started with Knapp (1964), who described two vegetation units on the island of Kefalonia. Since then, many researchers have studied the floristic composition and structure of Greek fir forests and several plant communities have been described from different mountains of southern and central Greece (Barbéro \& Quézel 1976, Dimopoulos et al. 1996, Bergmeier 2002, Karetsos 2002, Maroulis 2003, Dimitrellos 2005, Vlachos 2006, Kokmotos 2008, Samaras et al. 2008). For a detailed phytosociological review see Samaras (2012). However, the ecological causes underlying the floristic differentiation of the Greek fir forests have not yet been studied.

Although Greek fir can be found on soils originating from different bedrock including gneiss, serpentine, flysch, schist, limestone and dolomite, the species shows no association with a specific soil type (Schütt 1994). Its natural distribution ranges from 300 to $2300 \mathrm{~m}$ a.s.1. (Aussenac 2002, Gouvas \& Theodoropoulos 2014). It forms forests that extend from the middle and upper part of the meso-mediterranean zone (600-900 $\mathrm{m}$ a.s.1.) to the lower part of the oro-mediterranean zone (1900-2000 m a.s.l.), with an optimum distribution in the supra- and montanemediterranean vegetation zones (900-1900 m a.s.1. - Ozenda 1975, Quézel \& Barbéro 1985, Quézel 1998). In the area of its natural distribution the mean annual precipitation varies from $500 \mathrm{~mm}$ (lower elevations of SE Greece) to more than $1800 \mathrm{~mm}$ (western part of south-central Greece - Gouvas \& Sakellariou 2011). Greek fir forests receive abundant rainfall during autumn and winter, though may suffer from severe drought in summer (Aussenac 2002).

Drought is a complex environmental factor having both climatic and soil components. Drought-related variables have been successfully used to explain the distribution of vegetation types on local (Xystrakis 2009), regional (Stephenson 1998) and on continental to global scales (Stephenson 1990, Frank \& Inouyei 1994). Drought seems to play a crucial role in the floristic differentiation of Greek fir forests in southern Greece (Bergmeier 2002), but to which degree and how, is still not known. We hypothesize that drought could affect the floristic composition of the Greek fir forests in central Greece through their differentiation into distinct plant communities.

To test such hypothesis, we chose a representative mountain range in central Greece 


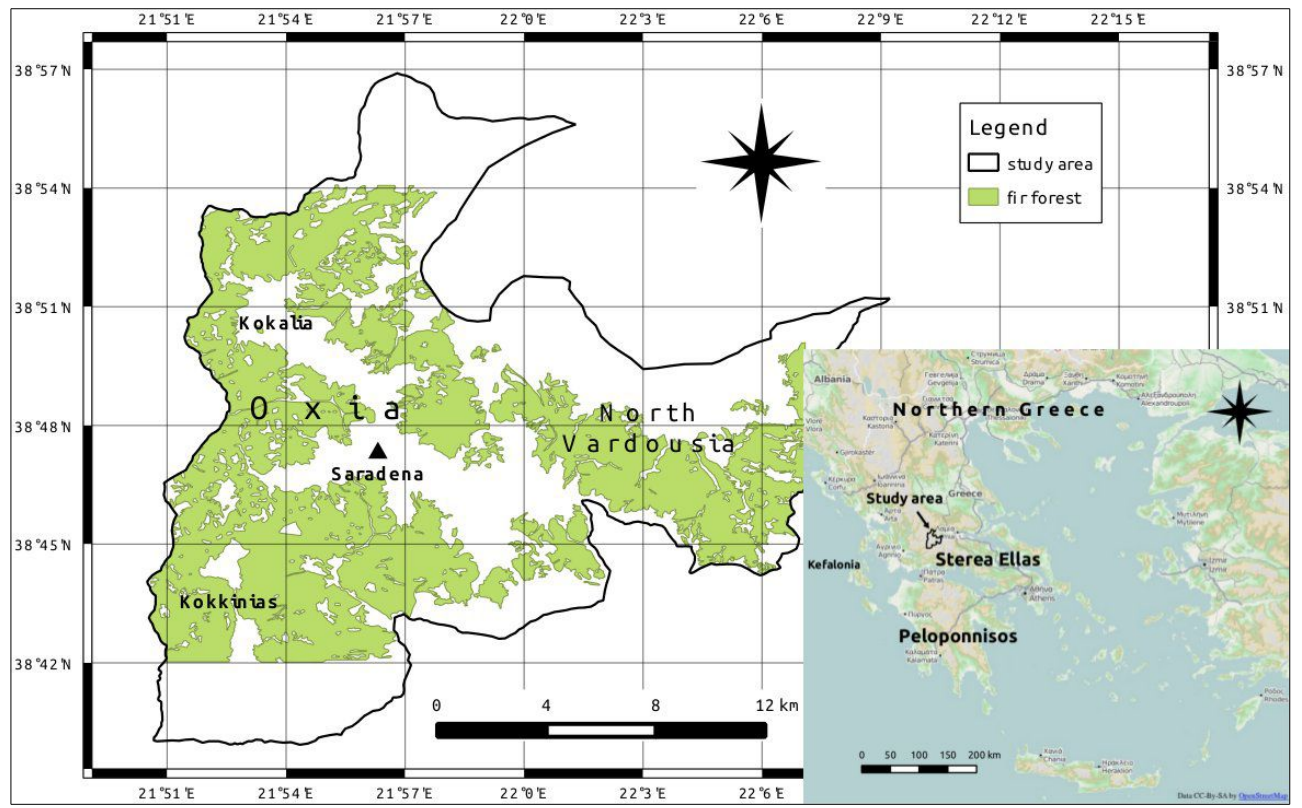

Fig. 1 - Map of the study area. Coordinate reference system: WGS 84 .

covered by extensive fir forests, to analyze and quantify the influence of drought on their floristic differentiation. Our objectives were:

- to describe the Greek fir plant communities found in the study area;

- to identify the components of drought that determine the floristic gradients in the Greek fir forests and;

- to quantify the influence of drought by determining a drought threshold among plant communities.

Because tree species composition of a forest is more likely to be influenced by human activities, we analyzed the ground vegetation composition. It has been demonstrated that ground vegetation can serve as an indicator of site conditions (Ellenberg \& Leuschner 2010). Furthermore, ground vegetation has been shown to be particularly useful in identifying the ecotones induced by drought (Sayer 2000, Gärtner et al. 2008, Xystrakis 2009).

\section{Material and methods}

\section{Study area}

The study area is located in the Oxia-North Vardousia mountain system in south-central Greece (Sterea Ellas). The area is characterized by three mountain ranges (Kokalia, Kokkinias and North Vardousia) reaching $1923 \mathrm{~m}$ a.s.l. (summit of Saradena). The ranges lie between $38^{\circ} 39^{\prime} 36^{\prime \prime}$ and $38^{\circ} 57^{\prime \prime}$ $0^{\prime \prime} \mathrm{N}$ of latitude and $21^{\circ} 50^{\prime} 24^{\prime \prime}$ and $22^{\circ} 9^{\prime}$ $0^{\prime \prime} \mathrm{E}$ of longitude, and cover an area of 414 $\mathrm{km}^{2}$ (Fig. 1)

The most abundant forest type in the region is the montane Greek fir coniferous forest, which covers $44.6 \%$ of the study area (Samaras 2012). Although the fir forest attains its optimum distribution in the supra-mediter- ranean zone (900-1400 m a.s.1.), it also occurs in the middle and upper part of the meso-mediterranean zone (600-900 m a.s.1. Samaras 2012). In the montane-mediterranean zone (1400-1900 $\mathrm{m}$ a.s.l.), the fir forest is one component of a matrix that also includes pastures and forest clearings. In this zone the forest area has declined due to grazing and logging.

The dominant bedrock on the Oxia-North Vardousia mountain system is flysch, while Jurassic limestones and scree slope (or terrace) deposits occur to a small extent (Kallergis et al. 1970). The climate is typically Mediterranean with wet, cool winters and dry summers. Nevertheless, there are large local differences due to the complexity and variety of the topography. January is the coldest month with an average minimum temperature between -2.7 and $0.7{ }^{\circ} \mathrm{C}$. The warmest month is July with an average maximum temperature between 23.1 and $28.6{ }^{\circ} \mathrm{C}$. The annual mean temperature ranges between 8.5 and $13.3{ }^{\circ} \mathrm{C}$. Most of the precipitation falls between October and April. Summer rains are scant and irregular, mostly in the form of thunderstorms. The annual precipitation varies from $1090 \mathrm{~mm}$ at the lower elevations ( $\sim 600 \mathrm{~m}$ a.s.1.) to $1710 \mathrm{~mm}$ at the higher $(\sim 1600 \mathrm{~m}$ a.s.l. - Samaras 2012).

\section{Quantification of drought}

There are two basic concepts of drought: the first considers it as a temporary climatic aberration (meteorological anomaly), characterized by a "prolonged and abnormal moisture deficiency" (Palmer 1965), while the second describes it as a seasonal climatic feature (also called aridity) occurring in places with well-defined rainy and dry seasons (Thornthwaite 1947). For our study we used the second concept.
Three different approaches for drought quantification were followed in this study (Wallén 1967):

- the classical approach using simple climatic variables: the main climatic factors related to drought, i.e., global (total) irradiation (Rs), air temperature (T), precipitation $(\mathrm{P})$, reference potential evapotranspiration (PETref), were spatially estimated for the study area and raster maps were generated for different time periods (monthly, driest period, vegetation period, growing season, and annual period - see Tab. 1 for the definitions);

- the second approach using an index obtained through the combination of two or more climatic factors related to drought: we used a modified version of the Transeau's humidity index (HI - Tuhkanen 1980), which combines the two main factors related to drought; the humidity index (HI) was calculated as the ratio of $\mathrm{P}$ to $\mathrm{PE}$ Tref (HI = P/PETref);

- the third approach (called "site water balance approach") considers also the soil components of drought, along with the above climatic factors: in this study both reference actual evapotranspiration (AETref) and water deficit (D) were included in the water balance; water deficit is defined as the difference between PETref and AETref (Stephenson 1990); for the calculation of the above variables, a monthly version of Thornthwaite's water balance model was applied (Willmott et al. 1985, Mintz \& Serafini 1992, Samaras 2012).

To calculate the monthly mean of daily Rs, the "r.sun" model (Hofierka \& Š́ri 2002, Súri \& Hofierka 2004) was used in the GRASS-GIS software version 6.4.0 (GRASS Development Team 2010). For the spatial estimation of $\mathrm{T}$ and $\mathrm{P}$, ordinary kriging, linear 
regression and regression-kriging models were used, taking into account the elevation and the spatial correlation of climatic data from 19 weather stations (Samaras 2012). The computational steps followed the general framework for geostatistical mapping of environmental variables (Hengl 2007). The PETref was calculated by using the empirical equation of Abtew (1996), which requires maximum air temperature (Tmax) and Rs values, calibrated for the local conditions (Samaras et al. 2014).

The methods used here for drought quantification took into account the spatial variation of fine-scale physiographic features such as elevation, slope, exposition and topographic shadowing effects. Any changes of these features within a distance of less than $100 \mathrm{~m}$ were considered as "microscale" changes, whereas those greater than $100 \mathrm{~m}$ were considered as "local-scale".

\section{Sampling design and data collection}

The humidity index (HI) was used to spatially quantify drought and to capture the whole range of drought intensity over the study area. The whole area was classified and mapped into four strata based on equal intervals of $\mathrm{HI}$ during the vegetation period (HI: $0.28-0.39,0.39-0.51,0.51-0.62,0.62$ $0.74)$. The underlying assumption was that the four strata represent forest site conditions, each with a different drought intensity. Based on the map of HI intervals obtained (Fig. 2), a total of 45 locations were randomly selected. At each location a rectangular plot of $200 \mathrm{~m}^{2}$ was sampled. In order to minimize the influence of environmental factors other than climate, only fir forest stands on flysch were sampled. Since no information were available on the anthropogenic disturbances at the different locations, this aspect was neglected.

In each plot, the species composition (including vascular plants and mosses growing on mineral soil or humus) was recorded. Structural information was obtained by assessing four layers of vegetation cover (moss, herb, shrub and tree). The moss layer included only mosses, while the herb layer included herbaceous and woody species up to $50 \mathrm{~cm}$ in height. The woody species between $50 \mathrm{~cm}$ and $5 \mathrm{~m}$ tall were included in the shrub layer, and those above $5 \mathrm{~m}$ in the tree layer. For all species and layers, the cover-abundance was estimated using the extended (9-point) Braun-Blanquet scale (Van Der Maarel 2005). Plant specimens were collected during the field work and stored in the herbarium of the Laboratory of Forest Botany-Geobotany in the Aristotle University of Thessaloniki, Greece (TAUF). The nomenclature of vascular plants follows, in order of priority, Flora Hellenica (Strid \& Tan 1997, Strid \& Tan 2002), Exkursionsflora für Kreta (Jahn \& Schönfelder 1995),

Tab. 1 - Climatic parameters and climatic-soil components of water balance used in the ordination (as fitted environmental vectors) and the recursive partitioning analysis (as explanatory variables). The variables were calculated for different time periods: monthly, driest period (the four driest months of the year - June-September), vegetation period (beginning of April until end of October), growing season (daily mean temperature remains above $6{ }^{\circ} \mathrm{C}$ ), and annual period.

\begin{tabular}{llcc}
\hline Group & Variable & Abbreviation & Units \\
\hline Climatic parameters & Mean air temperature & Tav & ${ }^{\circ} \mathrm{C}$ \\
& Minimum air temperature & Tmin & ${ }^{\circ} \mathrm{C}$ \\
& Maximum air temperature & Tmax & ${ }^{\circ} \mathrm{C}$ \\
& Precipitation & $\mathrm{P}$ & $\mathrm{mm}$ \\
& Global (total) radiation & $\mathrm{Rs}$ & $\mathrm{Mj} / \mathrm{m}^{2}$ \\
& Reference potential evapotranspiration & PETref & $\mathrm{mm}$ \\
& Humidity index & HI & dimensionless \\
\hline Climatic-soil compo- & Reference actual evapotranspiration & AETref & $\mathrm{mm}$ \\
nents of water balance & Water deficit & $\mathrm{D}$ & $\mathrm{mm}$ \\
\hline
\end{tabular}

Mountain Flora of Greece (Strid 1986, Strid \& Tan 1991), Med-Checklist (Greuter et al. 1984) and Flora Europaea (Tutin et al. 1980, 1993). The families Asteraceae, Poaceae and Rosaceae follow the more recent reviews of Euro+Med (2006). The nomenclature for orchids follows Baumann et al. (2006), and for mosses Hill et al. (2006). We based the evaluation of vascular plant ecological traits on Böhling et al. (2002), Pignatti et al. (2005) and Guarino et al. (2012). The nomenclature for the phytosociological units follows Horvat et al. (1974) and Bergmeier \& Dimopoulos $(2001,2008)$, and in accordance with the International Code of Phytosociological Nomenclature of Weber et al. (2000).

In each of the 45 sampling plots a pit was dug to expose the soil profile up to $1 \mathrm{~m}$ in depth or until the parent material was rea- ched. The rooting depth was measured and the soil skeleton content was estimated. Undisturbed soil samples were taken using soil sample rings of 100 and $163 \mathrm{~cm}^{3}$, and analyzed for the determination of the soil water retention curve (Dane \& Hopmans 2002). The soil data were used for the calculation of the available soil water storage capacity (ASWSC) of the total rooting space at each site (plot), expressed in mm. For details concernig the soil analysis and the calculation of ASWSC, see Samaras (2012). Additionally, topographic information was recorded for each plot including elevation, inclination, exposition, slope form and landscape position, as well as environmental conditions (humus depth, cover of litter and cover of exposed rocks and stones). Exposition (measured in degrees) is considered a poor va-

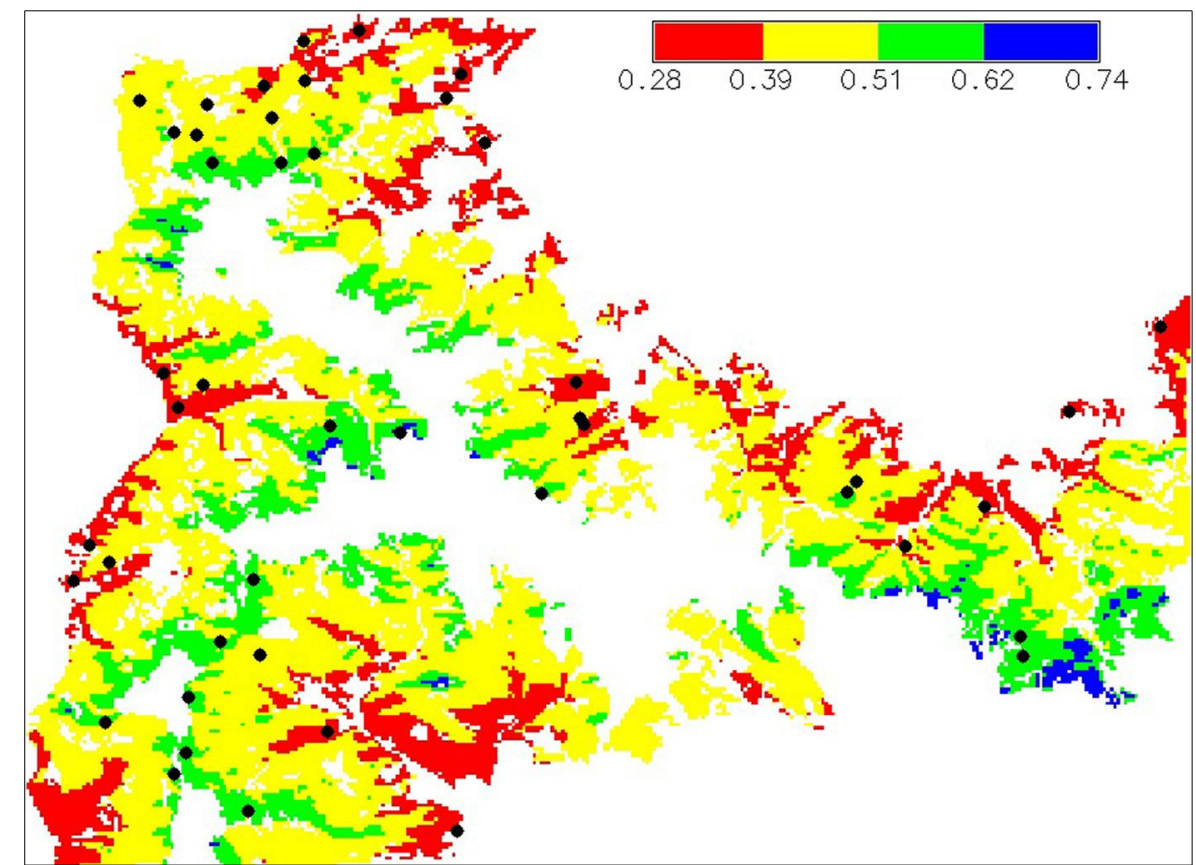

Fig. 2 - Stratification of the study area based on HI.veg values (humidity index of the vegetation period). Each stratum is indicated with a different color. The black dots indicate the locations of the 45 sampling plots. 
riable for quantitative analysis (McCune \& Keon 2002) and therefore was transformed prior to data analysis. Two new variables were created, "exposition to the north" and "exposition to the east", with the use of trigonometric functions (Leyer \& Wesche 2007).

\section{Data analysis}

The vegetation data was classified based on the floristic composition and species cover values. A hierarchical agglomerative cluster analysis based on Bray-Curtis distance (Bray \& Curtis 1957) was performed. Flexible beta (Lance \& Williams 1967) was used as a clustering algorithm, with $\beta=-0.25$. The original species cover-abundance values of the alpha-numeric extended Braun-Blanquet scale were replaced by the 1-9 Ordinal Transform Scale (OTS) proposed by Van Der Maabel (1979). In order to reduce the noise in the dataset, all infrequent taxa (occurring in only one or two plots) were discarded from the analysis. Data were organized using the database managing system TuRboveg (Hennekens \& Schaminée 2001). Cluster analysis was performed using the packages "cluster" (Maechler 2010), "vegan" (Oksanen et al. 2011) and "labdsv" (Roberts 2010) of the R software, version 2.12.2 (R Core Team 2011).

For the identification of the diagnostic taxa of vegetation units, fidelity values were calculated for each species using a modification of the $\Phi$ index (phi coefficient of association - Tichý \& Chytrý 2006). Species presence/ absence values were used as they provide more robust estimates of fidelity compared with cover values (Bruelheide 2000, Willner et al. 2009). The statistical significance of fidelity values was assessed by 1000 permutations of the species data (De Cáceres \& Legendre 2009). The fidelity value of each taxon was computed for each vegetation unit separately, compared with all others in the dataset, as well as for all possible combinations of units against the remaining units
(Tsiripidis et al. 2009, De Cáceres et al. 2010). The R package "indicspecies" (De Cáceres \& Jansen 2010) was used for this purpose.

Non-Metric Multidimensional Scaling (NMDS - Kruskal 1964a, 1964b) was applied to a Bray-Curtis distance matrix to identify the main vegetation gradients. The NMDS is considered the method of choice for ecological community data due to its flexibility and robustness (Kenkel \& Orloci 1986, Minchin 1987, Clarke 1993, Rydgren 1996, McCune \& Grace 2002). According to McCune \& Grace (2002), it does not require the normal distribution of the data nor linear relationships among variables, relieving the "zero-truncation" problem. NMDS allows the use of any distance measure (including semi-metric like Bray-Curtis) and preserves the ordering relationships (rank order) among objects. Additionally, NMDS tends to linearize the relationship between distances measured in species space and distances measured in environmental space (McCune \& Grace 2002). To identify the underlying environmental gradients, the environmental variables (Tab. 1, Tab. 2, Appendix 1) were fitted on the ordination axis. The significance of the relationships between the NMDS axis and the environmental variables was assessed with 1000 random permutations. We conducted the analysis with the functions "metaMDS" and "envfit" of the R package "vegan" (Oksanen et al. 2011).

To determine the influence of each drought related variable on vegetation patterns, recursive partitioning based on species composition was used to derive classification trees for the categorical response variable (Breiman et al. 1984). A non-parametric conditional inference tree approach was used (Hothorn et al. 2006) to explain the variation in the response variables (plant communities) as a function of the explanatory (environmental) variables, implemented in the $\mathrm{R}$ package "party" (Hothorn et al. 2011). At each step of the analysis, one explanatory variable was selected from all the available variables (Tab. 1, Tab. 2, Appendix 1), based on the best separation of two homogeneous groups using a permutation test. The split point was determined by a numerical value (threshold) of the explanatory variable. The relationships between the response and explanatory variables were presented in a dichotomous tree diagram, where nodes represent split points, while branches connecting nodes and leaves or terminal nodes represent the final groups.

\section{Results}

\section{Floristic differentiation of the Greek fir forest}

The classification of the vegetation plots analyzed revealed two distinct forest communities (indicated as A and B in Tab. 3), clearly distinguishable by their floristic and ecological characteristics (Appendix 2).

\section{(A) Crepis fraasii - Abies cephalonica com- munity}

General appearance: the community is comprised of pure stands of Abies cephalonica and mixed stands of $A$. cephalonica (dominant tree species) with Quercus frainetto and occasionally Castanea sativa. The shrub layer consists mainly of A. cephalonica, Juniperus oxycedrus ssp. oxycedrus and $Q$. frainetto. Many other woody species appear with low frequency in the shrub layer. Most of them are diagnostic elements of the Ostryo-Carpinion (Fraxinus ornus, Carpinus orientalis ssp. orientalis, Hippocrepis emerus ssp. emeroides etc. - Bergmeier \& Dimopoulos 2008).

Distribution: this community occurs on Mt. Oxia and Mt. Vardousia in the meso-mediterranean and the lower part of the supramediterranean zones between 690 and 1360 $\mathrm{m}$ a.s.l. It covers the upper, middle and lower sections of gentle to steep slopes $(25-90 \%)$ in all expositions (Fig. 3b, Fig. 3c).

Sub-communities: two sub-communities

Tab. 2 - Topographic, structural and environmental/abiotic conditions (mean \pm standard deviation) of each vegetation unit.

\begin{tabular}{|c|c|c|c|c|c|c|}
\hline Variable & $\underset{\text { A }}{\text { Community }}$ & $\begin{array}{c}\text { Sub-comm. } \\
\text { A1 }\end{array}$ & $\begin{array}{c}\text { Sub-comm. } \\
\text { A2 }\end{array}$ & $\underset{B}{\text { Community }}$ & $\begin{array}{c}\text { Sub-comm. } \\
\text { B1 }\end{array}$ & $\begin{array}{c}\text { Sub-comm. } \\
\text { B2 }\end{array}$ \\
\hline Elevation (m a.s.l) & $973 \pm 154$ & $928 \pm 127$ & $1005 \pm 168$ & $1375 \pm 143$ & $1401 \pm 152$ & $1303 \pm 85$ \\
\hline Inclination $(\%)$ & $52 \pm 16$ & $45 \pm 17$ & $56 \pm 14$ & $46 \pm 17$ & $50 \pm 15$ & $33 \pm 19$ \\
\hline Cover of tree layer $(\%)$ & $65 \pm 10$ & $71 \pm 11$ & $61 \pm 8$ & $67 \pm 14$ & $65 \pm 16$ & $73 \pm 6$ \\
\hline Cover of shrub layer (\%) & $19 \pm 13$ & $27 \pm 14$ & $13 \pm 7$ & $11 \pm 10$ & $12 \pm 11$ & $7 \pm 3$ \\
\hline Cover of herb layer (\%) & $31 \pm 24$ & $44 \pm 30$ & $22 \pm 14$ & $34 \pm 22$ & $31 \pm 23$ & $42 \pm 18$ \\
\hline Cover of moss layer $(\%)$ & $29 \pm 28$ & $28 \pm 31$ & $31 \pm 27$ & $8 \pm 7$ & $8 \pm 7$ & $7 \pm 9$ \\
\hline Total vegetation cover $(\%)$ & $80 \pm 10$ & $89 \pm 8$ & $74 \pm 7$ & $81 \pm 9$ & $80 \pm 9$ & $85 \pm 5$ \\
\hline Cover of litter $(\%)$ & $28 \pm 23$ & $37 \pm 25$ & $21 \pm 20$ & $43 \pm 29$ & $33 \pm 22$ & $72 \pm 29$ \\
\hline Cover of exposed rocks and stones $(\%)$ & $20 \pm 21$ & $23 \pm 22$ & $18 \pm 22$ & $22 \pm 18$ & $28 \pm 17$ & $4 \pm 1$ \\
\hline Height of highest trees $(\mathrm{m})$ & $18 \pm 3$ & $20 \pm 3$ & $17 \pm 3$ & $21 \pm 4$ & $21 \pm 4$ & $22 \pm 6$ \\
\hline Diameter of highest trees $(\mathrm{cm})$ & $45 \pm 10$ & $42 \pm 8$ & $47 \pm 10$ & $52 \pm 23$ & $51 \pm 20$ & $56 \pm 32$ \\
\hline Humus depth $(\mathrm{cm})$ & $3 \pm 2$ & $3 \pm 2$ & $4 \pm 2$ & $4 \pm 3$ & $4 \pm 3$ & $2 \pm 1$ \\
\hline Soil depth $(\mathrm{cm})$ & $66 \pm 31$ & $79 \pm 33$ & $57 \pm 28$ & $75 \pm 27$ & $78 \pm 26$ & $67 \pm 32$ \\
\hline ASWSC (mm) & $92 \pm 65$ & $119 \pm 76$ & $73 \pm 52$ & $128 \pm 66$ & $122 \pm 56$ & $146 \pm 93$ \\
\hline
\end{tabular}


Tab. 3 - Synoptic table of the fir forest vegetation units (communities and sub-communities) in the study area based on cluster analysis (fle xible beta with $\beta=-0.25$, Bray-Curtis distance). Frequency values of taxa are displayed. Only the diagnostic taxa are presented with their fi delity values $(\Phi)$ and their statistical significances. $(*): \mathrm{p}<0.05,(* *): \mathrm{p}<0.01,(* * *): \mathrm{p}<0.001$. The frequency values of taxa considered as diagnostic for the vegetation units are reported in italic. Woody species occurring in different layers are referred to with a letter $(\mathrm{t}=\mathrm{tree} ; \mathrm{s}=$ shrub; $\mathrm{h}=$ herb). Mosses are referred to with the letter $\mathrm{m}$. Communities and sub-communities: (A): Crepis fraasii-Abies cephalonica comm.; (A1): Sub-comm. with Castanea sativa; (A2): Sub-comm. with Trifolium grandiflorum; (B): Sanicula europaea-Abies cephalonica comm.; (B1): Sub-comm. with Silene multicaulis ssp. multicaulis; (B2): Sub-comm. with Rubus hirtus; (C): Common diagnostic taxa of two or more vegetation units.

\begin{tabular}{|c|c|c|c|c|c|c|c|c|c|c|c|c|c|c|c|}
\hline \multirow{2}{*}{ 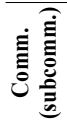 } & \multirow[b]{2}{*}{ Species } & \multirow[b]{2}{*}{ E } & \multicolumn{2}{|c|}{$A(n=22)$} & \multicolumn{2}{|c|}{ B (n=23) } & \multirow[b]{2}{*}{$\Phi$} & \multirow{2}{*}{ 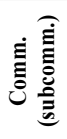 } & \multirow[b]{2}{*}{ Species } & \multirow[b]{2}{*}{ हే } & \multicolumn{2}{|c|}{$A(n=22)$} & \multicolumn{2}{|c|}{$B(n=23)$} & \multirow[b]{2}{*}{$\Phi$} \\
\hline & & & 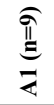 & $2 \stackrel{\frac{\pi}{\pi}}{\underline{E}}$ & $-\frac{E}{\pi}$ & 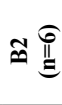 & & & & & 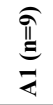 & 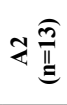 & $-\stackrel{\overbrace{}}{\stackrel{E}{\|}}$ & 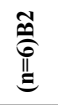 & \\
\hline \multirow[t]{10}{*}{ (A) } & Crepis fraasii & - & 67 & 92 & 6 & 0 & $0.778 * * *$ & (A2) & Torilis arvensis & - & 0 & 31 & 0 & 0 & $0.5 *$ \\
\hline & Quercus frainetto & $\mathrm{t}$ & 44 & 23 & 0 & 0 & $0.451 *$ & & Syntrichia ruralis & $\mathrm{m}$ & 0 & 31 & 0 & 0 & $0.5 *$ \\
\hline & Quercus frainetto & $\mathrm{s}$ & 56 & 54 & 6 & 0 & $0.571 * *$ & & Asplenium adiantum-nigrum & - & 33 & 69 & 18 & 0 & $0.493 *$ \\
\hline & Quercus frainetto & $\mathrm{h}$ & 100 & 100 & 24 & 33 & $0.746 * * *$ & & Cota tinctoria ssp. parnassica & - & 22 & 62 & 18 & 0 & $0.48 *$ \\
\hline & Juniperus oxycedrus ssp. oxycedrus & $\mathrm{s}$ & 78 & 92 & 24 & 0 & $0.733 * * *$ & & Hypericum spruneri & - & 33 & 69 & 24 & 0 & $0.469 *$ \\
\hline & $\begin{array}{l}\text { Hypnum cupressiforme var. } \\
\text { cupressiforme }\end{array}$ & $\mathrm{m}$ & 100 & 92 & 65 & 33 & $0.528 * *$ & & Neotinea maculata & - & 11 & 46 & 12 & 0 & $0.442 *$ \\
\hline & Thymus longicaulis ssp. chaubardii & - & 67 & 85 & 29 & 17 & $0.526 * *$ & (B) & Epilobium lanceolatum & - & 0 & 23 & 88 & 67 & $0.663 * * *$ \\
\hline & Homalothecium aureum & $\mathrm{m}$ & 67 & 92 & 41 & 17 & $0.507 * *$ & & Poa nemoralis ssp. nemoralis & - & 11 & 0 & 88 & 50 & $0.657 * * *$ \\
\hline & Trifolium patulum & - & 44 & 46 & 6 & 0 & $0.495 *$ & & Sanicula europaea & - & 33 & 8 & 88 & 83 & $0.654 * * *$ \\
\hline & Galium mollugo agg. & - & 56 & 62 & 18 & 17 & $0.427 *$ & & Viola reichenbachiana $\times$ riviniana & - & 11 & 0 & 47 & 83 & $0.624 * * *$ \\
\hline \multirow[t]{15}{*}{ (A1) } & Rosa arvensis & $\mathrm{h}$ & 67 & 0 & 0 & 0 & $0.775 * * *$ & & Fragaria vesca & - & 0 & 0 & 53 & 50 & $0.589 * *$ \\
\hline & Scutellaria columnae ssp. columnae & - & 56 & 0 & 0 & 0 & $0.696 * *$ & & Lapsana communis & - & 11 & 15 & 71 & 67 & $0.563 * *$ \\
\hline & Rubus canescens & s & 44 & 0 & 0 & 0 & $0.612 * *$ & & Lactuca muralis & - & 56 & 46 & 94 & 100 & $0.526 * *$ \\
\hline & Hedera helix ssp. helix & s & 33 & 0 & 0 & 0 & $0.522 * *$ & & Pteridium aquilinum ssp. aquilinum & - & 44 & 38 & 82 & 100 & $0.526 * *$ \\
\hline & Hedera helix ssp. helix & $\mathrm{h}$ & 56 & 15 & 0 & 0 & $0.572 * *$ & & Geum urbanum & - & 0 & 0 & 35 & 50 & $0.521 *$ \\
\hline & Viola alba ssp. alba & - & 56 & 0 & 0 & 17 & $0.563 * *$ & & Geocaryum capillifolium & - & 22 & 15 & 76 & 50 & $0.452 *$ \\
\hline & Cyclamen hederifolium & - & 33 & 0 & 0 & 0 & $0.522 *$ & (B1) & Silene multicaulis ssp. multicaulis & - & 0 & 8 & 82 & 0 & $0.827 * * *$ \\
\hline & Asplenium onopteris & - & 44 & 15 & 0 & 0 & $0.477 *$ & & Rumex acetosella ssp. acetoselloides & - & 0 & 15 & 59 & 0 & $0.598 * *$ \\
\hline & Platanthera montana & - & 33 & 0 & 6 & 0 & $0.457 *$ & & Arabis alpina ssp. caucasica & - & 0 & 0 & 35 & 0 & $0.539 * *$ \\
\hline & Ruscus aculeatus & $\mathrm{s}$ & 22 & 0 & 0 & 0 & $0.42 *$ & & Myosotis sylvatica ssp. cyanea & - & 56 & 31 & 100 & 50 & $0.48 *$ \\
\hline & Ruscus aculeatus & $\mathrm{h}$ & 33 & 8 & 0 & 0 & $0.439 *$ & & Arrhenatherum elatius & - & 11 & 0 & 47 & 17 & $0.42 *$ \\
\hline & Castanea sativa & $\mathrm{s}$ & 56 & 15 & 6 & 17 & $0.439 *$ & (B2) & $\begin{array}{l}\text { Geranium robertianum ssp. } \\
\text { purpureum }\end{array}$ & - & 22 & 8 & 12 & 100 & $0.78 * * *$ \\
\hline & Carex flacca ssp. serrulata & - & 22 & 0 & 0 & 0 & $0.42 *$ & & Rubus hirtus & $\mathrm{h}$ & 11 & 0 & 12 & 83 & $0.742 * * *$ \\
\hline & Scabiosa sp. & - & 22 & 0 & 0 & 0 & $0.42 *$ & & Moehringia trinervia & - & 0 & 0 & 6 & 50 & $0.6 * *$ \\
\hline & Trifolium heldreichianum & - & 22 & 0 & 0 & 0 & $0.42 *$ & & Bromopsis riparia & - & 0 & 0 & 29 & 67 & $0.576 * * *$ \\
\hline \multirow[t]{17}{*}{ (A2) } & Trifolium grandiflorum & - & 22 & 100 & 0 & 0 & $0.87 * * *$ & & Ilex aquifolium & s & 0 & 0 & 0 & 33 & $0.522 *$ \\
\hline & Origanum vulgare ssp. hirtum & - & 11 & 85 & 0 & 0 & $0.821 * * *$ & & Polystichum lonchitis & - & 0 & 0 & 0 & 33 & $0.522 *$ \\
\hline & $\begin{array}{l}\text { Myosotis ramosissima ssp. } \\
\text { ramosissima }\end{array}$ & - & 0 & 85 & 12 & 0 & $0.817 * * *$ & & $\begin{array}{l}\text { Tephroseris integrifolia } \text { ssp. } \\
\text { integrifolia }\end{array}$ & - & 0 & 0 & 0 & 33 & $0.522 *$ \\
\hline & Anisantha sterilis & - & 0 & 69 & 0 & 0 & $0.792 * * *$ & & Epipactis greuteri ssp. preinensis & - & 0 & 0 & 18 & 50 & $0.51 * *$ \\
\hline & Trifolium arvense & - & 0 & 69 & 6 & 0 & $0.746 * * *$ & & Calamintha grandiflora & - & 22 & 0 & 24 & 67 & $0.495 *$ \\
\hline & Cistus creticus ssp. creticus & $\mathrm{h}$ & 11 & 69 & 0 & 0 & $0.708 * * *$ & (C) & Dactylis glomerata & - & 100 & 77 & 53 & 0 & $0.671 * * *$ \\
\hline & Trifolium physodes & - & 44 & 100 & 29 & 0 & $0.658 * * *$ & & Campanula spatulata ssp. spruneriana & - & 78 & 100 & 82 & 17 & $0.657 * * *$ \\
\hline & Cerastium brachypetalum ssp. roeseri & - & 33 & 100 & 47 & 0 & $0.637 * * *$ & & Doronicum orientale & - & 44 & 77 & 82 & 0 & $0.588 * *$ \\
\hline & Festuca circummediterranea & - & 0 & 62 & 18 & 0 & $0.605 * *$ & & Cynosurus effusus & - & 56 & 85 & 59 & 0 & $0.574 * *$ \\
\hline & Cynosurus echinatus & - & 0 & 54 & 12 & 0 & $0.584 * *$ & & Juniperus oxycedrus ssp. oxycedrus & $\mathrm{h}$ & 56 & 85 & 41 & 0 & $0.526 * *$ \\
\hline & Vicia lathyroides & - & 22 & 77 & 24 & 0 & $0.579 * *$ & & Pilosella piloselloides ssp. bauhinii & - & 56 & 77 & 41 & 0 & $0.506 *$ \\
\hline & Trifolium scabrum & - & 0 & 38 & 0 & 0 & $0.565 * *$ & & Cardamine hirsuta & - & 33 & 100 & 82 & 0 & $0.747 * * *$ \\
\hline & Trifolium ochroleucon & - & 0 & 46 & 12 & 0 & $0.52 *$ & & Carlina biebersteinii et corymbosa & - & 22 & 77 & 71 & 0 & $0.634 * * *$ \\
\hline & Anthyllis vulneraria ssp. bulgarica & - & 0 & 31 & 0 & 0 & $0.5 *$ & & Pilosella hoppeana ssp. testimonialis & - & 0 & 46 & 29 & 0 & $0.483 *$ \\
\hline & Chamaecytisus austriacus & - & 0 & 31 & 0 & 0 & $0.5 *$ & & Sedum amplexicaule ssp. tenuifolium & - & 0 & 46 & 29 & 0 & $0.483 *$ \\
\hline & Lathyrus digitatus & - & 0 & 31 & 0 & 0 & $0.5 *$ & & Sanguisorba minor ssp. muricata & - & 0 & 31 & 35 & 0 & $0.445 *$ \\
\hline & Leontodon tuberosus & - & 0 & 31 & 0 & 0 & $0.5 *$ & & Sedum hispanicum & - & 0 & 38 & 24 & 0 & $0.428 *$ \\
\hline
\end{tabular}

could be distinguished (A1 and A2 - Tab. 3). The first was characterized by the presence of Castanea sativa and a group of typically semi-shade to semi-light forest plants (Böhling et al. 2002, Pignatti et al. 2005). Most of these species (such as Rosa arvensis, Scutellaria columnae ssp. columnae, Rubus canescens, Viola alba ssp. alba, Platanthera montana, Ruscus aculeatus are diagnostic of the sub-mediterranean thermophilous oak woodlands (Quercet(-ea)alia pubescentis Mucina 1997, Bergmeier \& Dimopoulos 2008). Abies cephalonica dominates and together with Castanea sativa, Juniperus oxycedrus ssp. oxycedrus and Quercus frainetto forms a moderately dense shrub layer cove- ring up to $45 \%$ of the surface (average cover $27 \%$ - Tab. 2). This sub-community is restricted to the mountain range of Oxia. The second sub-community (A2) with Trifolium grandiflorum was characterized by a large group of plants that indicate low nutrient availability (Tab. 3). Most of these taxa are semi-light to light-demanding thermophilous plants indicative of grasslands and other open plant communities (Myosotis ramosissima ssp. ramosissima, Trifolium arvense, Cistus creticus ssp. creticus, Festuca circummediterranea, Cynosurus echinatus, Vicia lathyroides, T. scabrum etc. - Mucina 1997, Böhling et al. 2002, Pignatti et al. 2005). Such taxa reflect not only the stand structure but also some site characteristics which differ from the previous sub-community (A1). The stands are more open (average cover almost $60 \%$ - Tab. 2) and established preferentially on south facing and steep slopes (Fig. 3b, Fig. 3c), though their elevation range does not differ from the previous subcommunity (Fig. 3a). The shrub layer is less dense and species-rich as compared with the previous sub-community, and mainly composed by Abies cephalonica and Juniperus oxycedrus ssp. oxycedrus. The shrub layer covers up to $25 \%$ of the surface with an average of $13 \%$ (Tab. 2). This sub-community is distributed throughout the study area. 

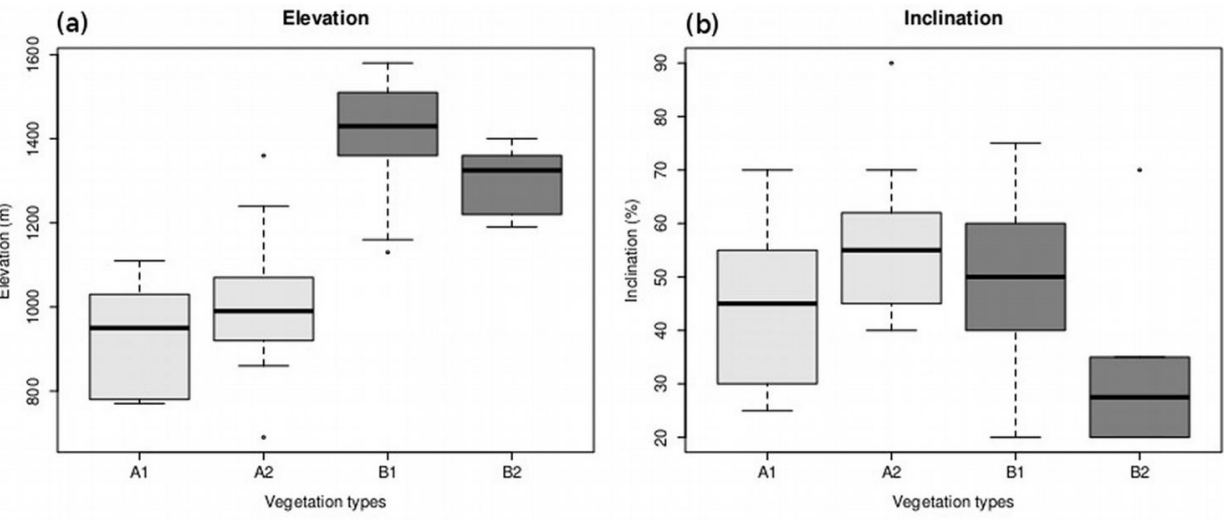

Fig. 3 - Boxplots of the environmental variables in the different vegetation units. Median, mid-spread and range of variables are displayed. For the mid-spread (interquartile range) the $25 \%$ and $75 \%$ quartiles were used. Whiskers extend up to 1.5 times the interquartile range. Outliers are indicated with small circles. Rockiness (f) is the cover of exposed rocks and stones. The exposition to the north (c) is dimensionless, ranging from -1 (south) to 1 (north).

(c)

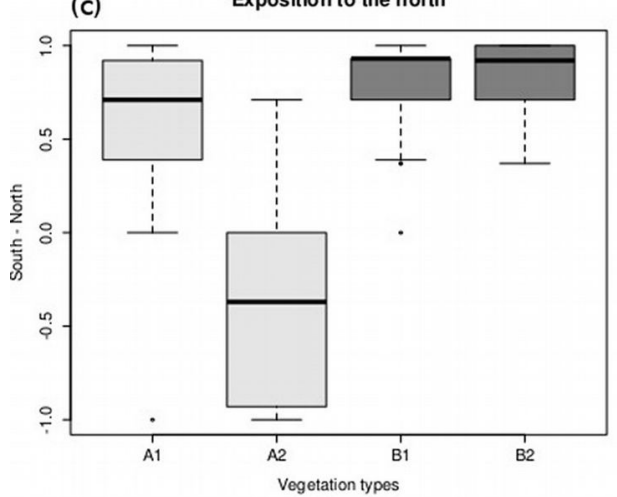

(e)

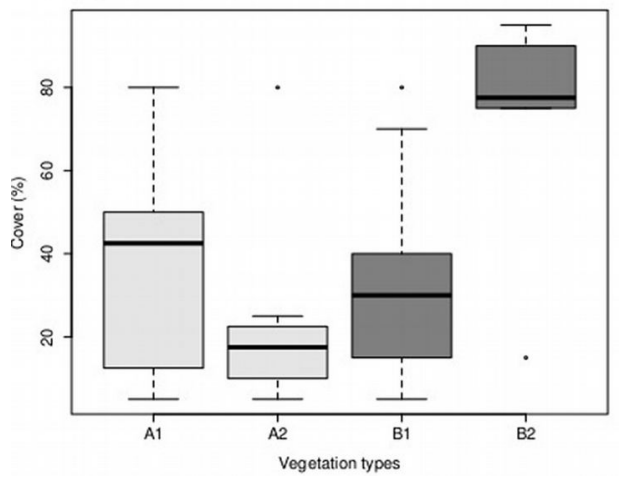

(d)
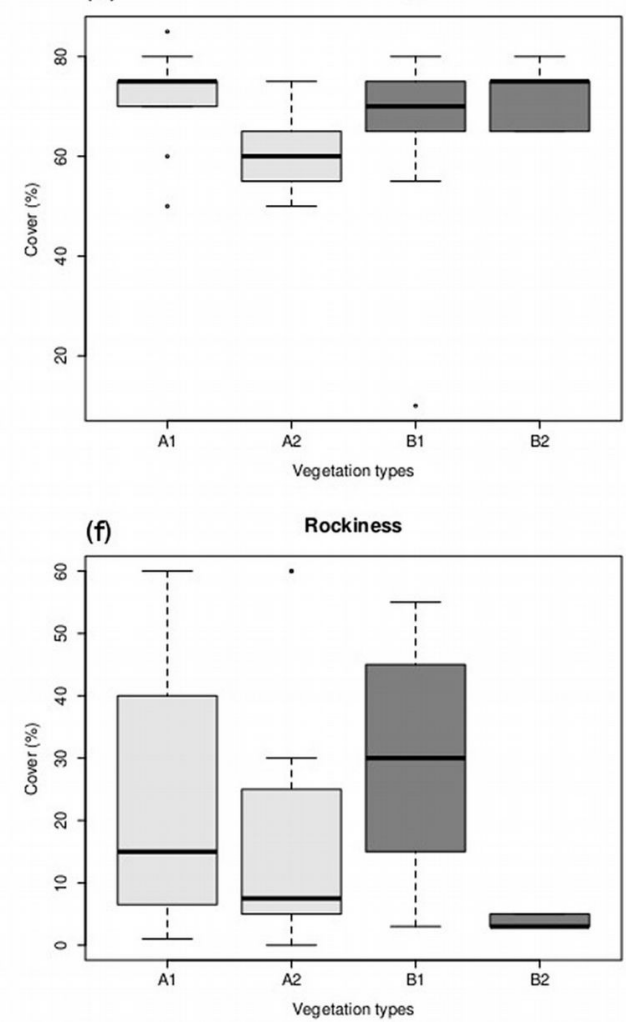

(B) Sanicula europaea - Abies cephalonica community

General appearance: this community is made up of pure Abies cephalonica forest stands. In the shrub layer A. cephalonica predominates and other woody species $(\mathrm{Ju}$ niperus oxycedrus ssp. oxycedrus, Castanea sativa, Fagus sylvatica ssp. sylvatica, Ilex aquifolium, etc.) are only rarely found. It was differentiated from the previous community by a group of species indicating moderately moist to fresh and warm (not hot) conditions.

Distribution: this community can be found on Mt. Oxia and Mt. Vardousia at higher altitude (1130-1580 m a.s.1.) as compared with community A (Fig. 3a). It ranges up to the lower part of the montane-mediterranean zone and reaches the timberline. It is largely restricted to the upper and middle parts of north facing slopes.

Sub-communities: two sub-communities may be distinguished (B1 and B2 - Tab. 3). The first sub-community with Silene multicaulis ssp. multicaulis (B1) was characterized by a small group of diagnostic taxa, while the second sub-community with Rubus hirtus (B2), was differentiated by a larger group of taxa. The distribution of sub-community B2 is restricted to the northwest part of the study area, mainly on gentle slopes with very few rocks and a north to northeast orientation (Fig. 3b, Fig. 3c, Fig. 3f).

\section{Plant communities along the drought gradient}

Multivariate analysis on floristic data allowed to identify two main vegetation gra- dients in the study area. The first floristic gradient was depicted by the horizontal axis (NMDS1) of the ordination diagram displayed in Fig. 4. The two plant communities described above (A: Crepis fraasii-Abies cephalonica and B: Sanicula europaeaAbies cephalonica) appeared well differentiated along the NMDS1 (horizontal) axis. The second floristic gradient, depicted by the vertical axis (NMDS2) of the ordination diagram displayed in Fig. 4, differentiated the sub-communities within the $\mathrm{A}$ and $\mathrm{B}$.

The underlying ecological gradients were detected by fitting the different environmental variables onto the ordination scores (Fig. $5)$. The direction of the environmental vectors (Fig. 5) and their coefficients of determination (Tab. 4, Appendix 1) indicate the direction and the strength of the ecological 
gradients respectively. The first floristic gradient (NMDS1) reflects a climatic gradient related to drought. Almost all of the climatic (T, P, PETref, HI) and the edapho-climatic (D, AETref) components of drought were strongly correlated with the horizontal axis (Fig. 5, Tab. 4). Temperature and precipitation showed the highest correlation with the horizontal axis for all the periods analyzed (driest, vegetation and annual), except for the growing season (Tab. 4, Appendix 1). The left part of the ordination diagram depicted in Fig. 5, occupied by the community A (Crepis fraasii-Abies cephalonica), represents areas with low elevation and low humidity, while the right part, occupied by the community B (Sanicula europaea-Abies cephalonica), represents the more humid areas of the high-altitude fir forest (Fig. 4, Fig. 5).

Differences in topography (exposition and inclination - Fig. 3b, Fig. 3c), soil water availability (ASWSC - Tab. 2) and stand structure (cover of tree layer - Fig. 3d) were found between the sub-communities A1 and A2. These structural, topographic and edaphic changes along the vertical axis result in specific micro-climatic conditions that differentiate the two sub-communities at a micro-scale (a scale of tens of meters). In the case of the community B (Sanicula europaea-Abies cephalonica), the structural differentiation between its two sub-communities B1 and B2 was less apparent (Fig. 3d). The main topographic difference between $\mathrm{B} 1$ and B2 was related to slope steepness (Fig. $3 b)$. Despite their dissimilarity in rockiness (Fig. 3f), their difference in ASWSC was very small (Tab. 2). However, higher accumulation of litter on the surface was detected for B2 (Rubus hirtus sub-community - Fig. 3e).

\section{Threshold values of drought}

Recursive partitioning based on the $\mathrm{HI}$ during the driest period (HI.dry) revealed the

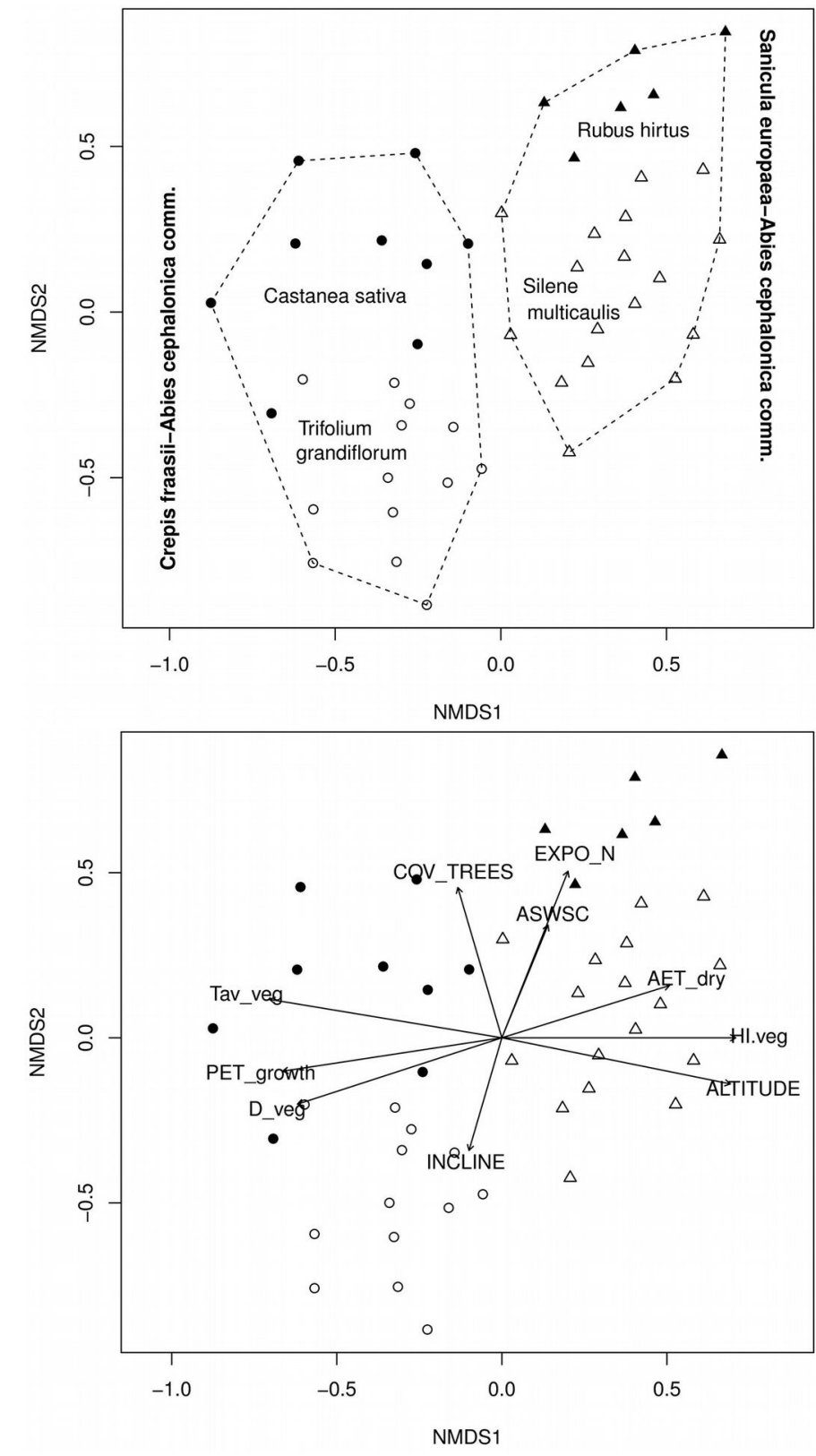

Fig. 4 - Distribution of the vegetation units along the two axes (NMDS1, NMDS2) of the ordination (NMDS). The different symbols indicate site groups (vegetation units) formed by the cluster analysis. The envelopes comprise the two main plant communities A and B. The stress for the solution with two axes is equal to 13.6 .

Fig. 5 - Projection of the environmental variables (as vectors) on the ordination axes (NMDS). The direction and strength of the gradients is represented by the direction and length of the vectors respectively. For the abbreviations of the environmental variables and their coefficients of determination see Tab. 4.

Tab. 4 - Relationships between the species ordination's scores (NMDS) and the fitted environmental variables. Coefficients of determination $\left(\mathrm{r}^{2}\right)$ and their significances assessed using 1000 random permutations. Only variables with significant coefficients are shown. $(*)$ : $p<0.05$; $(* *): \mathrm{p}<0.01 ;(* * *): \mathrm{p}<0.001$.

\begin{tabular}{|c|c|c|}
\hline Variables & Abbreviations & $\mathbf{r}^{2}$ \\
\hline Elevation (m a.s.1.) & ALTITUDE & $0.843 * * *$ \\
\hline Inclination $(\%)$ & INCLINE & $0.205 *$ \\
\hline Exposition to the north & EXPO_N & $0.487 * * *$ \\
\hline Cover of tree layer $(\%)$ & COV_T̄TEES & $0.394 * * *$ \\
\hline Available soil water storage capacity $(\mathrm{mm})$ & ASWSC & $0.215 * *$ \\
\hline Solar radiation during growing period $\left(\mathrm{Mj} / \mathrm{m}^{2}\right)$ & Rs_growth & $0.522 * * *$ \\
\hline Maximum air temperature during driest period $\left({ }^{\circ} \mathrm{C}\right)$ & Tmax_dry & $0.857 * * *$ \\
\hline Mean air temperature during vegetation period $\left({ }^{\circ} \mathrm{C}\right)$ & Tav veg & $0.856 * * *$ \\
\hline Precipitation during vegetation period $(\mathrm{mm})$ & P_veg & $0.852 * * *$ \\
\hline Reference actual evapotranspiration during driest period (mm) & AET_dry & $0.462 * * *$ \\
\hline Reference potential evapotranspiration during growing period $(\mathrm{mm})$ & PET_growth & $0.753 * * *$ \\
\hline Humidity index during driest period & HI_dry & $0.824 * * *$ \\
\hline Humidity index during vegetation period & HI_veg & $0.839 * * *$ \\
\hline Water deficit during driest period (mm) & D_dry & $0.690 * * *$ \\
\hline Water deficit during vegetation period (mm) & D_veg & $0.696 * * *$ \\
\hline
\end{tabular}




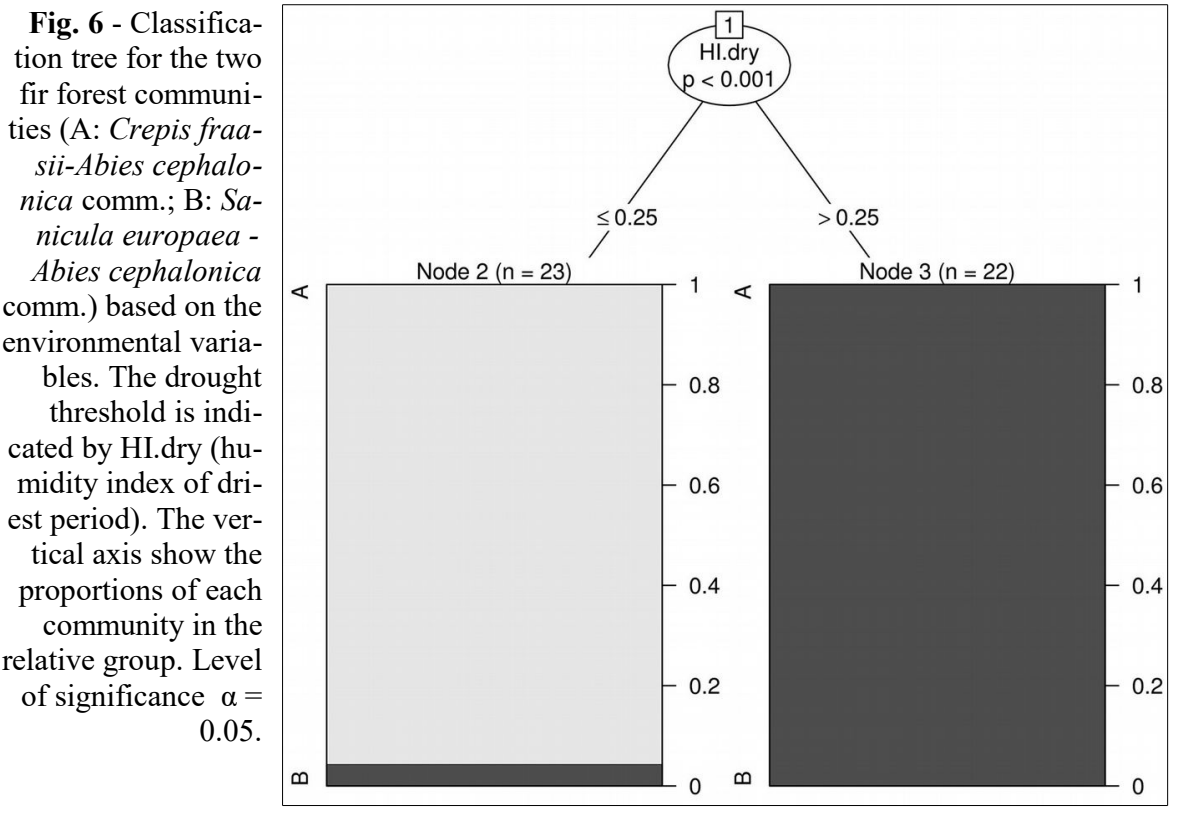

existence of two groups of plots (Fig. 6). HI.dry was the best discriminating variable among all the factors analyzed ( $\mathrm{p}$-value < 0.001 ). The first group (Fig. 6, left panel) included all plots where $\mathrm{HI}$ of the driest period was less or equal to 0.25 (all plots from community A plus one plot from community B). The second group (Fig. 6, right panel) included all plots where HI of the driest period was higher than 0.25 (the majority of the plots belonging to the B community, except for one that was misclassified). No further plot subgrouping was detected using any of the remaining environmental variables analyzed in this study.

\section{Discussion}

\section{Syntaxonomy of the Greek fir forests}

The Crepis fraasii-Abies cephalonica community has many floristic elements in common with the association Trifolio grandiflori-Abietetum borisii-regis Barbéro \& Quézel 1976. This association was described by Barbéro \& Quézel (1976) from the mountains of Oxia, Timfristos and South Vardousia and confirmed later by Dimitrellos (2005) and Vlachos (2006) for Timfristos and South Vardousia, respectively. The actual distribution of the association is still unknown, though it seems restricted to the northern and western part of Sterea Ellas. The small number of relevés used by Barbéro \& Quézel (1976), Dimitrellos (2005) and Vlachos (2006) to describe this association (14-15 in each study) did not allow a full delineation of the Trifolio grandifloriAbietetum borisii-regis. From the character species of the association (Abies borisiiregis, Trifolium grandiflorum, Trifolium aurantiacum, Luzula forsteri, Helleborus odorus ssp. cyclophyllus and Cicer montbretii), given by Barbéro \& Quézel (1976), only Trifolium grandiflorum has a diagnostic value for the sub-community $\mathrm{A} 2$, but it is almost absent from the more dense north facing stands represented by the sub-community A1 with Castanea sativa. Therefore, despite their floristic similarity and geographic closeness, we decided to describe this fir forest type of the lower elevation zone as a rankless Crepis fraasii-Abies cephalonica community (and not an association).

The Sanicula europaea-Abies cephalonica community shares many floristic elements with the association Lilio chalcedonicaeAbietetum cephalonicae Barbéro \& Quézel (1976). This association was first described by Barbéro \& Quézel (1976) from different mountains of Peloponnisos and later confirmed by several authors not only in southern Greece (Dimopoulos et al. 1996, Bergmeier 2002), but also in central Greece (Karetsos 2002, Dimitrellos 2005, Vlachos 2006, Kokmotos 2008). Several taxa have "character or diagnostic species" of the Lilio ium chalcedonicum, Calamintha grandiflora, Ribes uva-crispa, Polygonatum multiflorum, Scilla bifolia, Stellaria cupaniana, Galium taygeteum, Digitalis ferruginea etc.). Most of these species were recorded in only one or few locations and should therefore be considered as local diagnostic taxa. Lilium chalcedonicum is the only species that is present on almost all of the sites where the above association is described. In this study, Lilium chalcedonicum was not detected in any of the plots, though it occurs in the study area. The species grows mainly in forest gaps or edges, and not in the interior of forest stands. Common floristic elements can be also found between the Sanicula eurobeen described by the above authors as chalcedonicae-Abietetum cephalonicae (Lil-
paea-Abies cephalonica community and the Abies cephalonica community from the neighboring Mt. Iti (Karetsos 2002). Taxa with common diagnostic values between the two communities are: Lapsana communis, Pteridium aquilinum ssp. aquilinum and $\mathrm{Ar}$ rhenatherum elatius. The Abies cephalonica community, though very similar to the association Lilio chalcedonicae-Abietetum cephalonicae, is also distinguished by the absence of Lilium chalcedonicum. Based on the above considerations, we decided to describe this fir forest type of the higher elevation zone as a rankless Sanicula europaeaAbies cephalonica community (and not an association).

Horvat et al. (1974) assigned all fir forests of southern Greece to the Abietion cephalonicae alliance without providing any character species group. Barbéro \& Quézel (1976) assigned the fir and black pine forests of southern Greece to the Abieti-Pinion alliance. The names Abietion cephalonicae and Abieti-Pinion have been alternatively used since then by several authors and are now considered as synonyms. Following Bergmeier (2002), the name Abietion cephalonicae Horvat et al. 1974 was adopted and used in this study to describe the fir forests of the area. The presence of many diagnostic taxa of the order Quercetalia pubescenti-petraeae Klika 1933 in the two communities analyzed (Appendix 2) indicates their close floristic relation to the thermophilous deciduous forests. At the class level, there is an ongoing debate whether to include thermophilous deciduous forests of south-eastern Europe together with beech forests into Querco-Fagetea, or to separate them into distinct classes (Blasi et al. 2004). Following the recent syntaxonomical revisions for Greece by Bergmeier \& Dimopoulos (2001, 2008), we decided to include the fir forests of central Greece in Quercetea pubescentis Doing-Kraft ex Scamoni et Passarge 1959.

In contrast to the aforementioned authors (Horvat et al. 1974, Barbéro \& Quézel 1976, Bergmeier 2002), Brullo et al. (2001) included the orophilous communities (above $1500 \mathrm{~m}$ a.s.1.) of Greek fir of central Greece in the Berberido creticae-Juniperion foetidissimae alliance of the Pino-Juniperetea class. This class describes the open coniferous woodlands and shrublands of the suprato oro-Mediterranean zones characterized by the lack of nemoral species and does not apply to the more or less dense Greek fir forests in the study area. A broad syntaxonomic review of all fir forests in Greece is needed to relate all fir forest vegetation units to a wider phytogeographical background, giving a better understanding of their floristic differentiation.

A syntaxonomic synopsis for the communities analyzed in this study is given below: Class: Quercetea pubescentis Doing-Kraft 
ex Scamoni et Passarge 1959

Order: Quercetalia pubescenti-petraeae Klika 1933

Alliance: Abietion cephalonicae Horvat et al. 1974

1. Community: Crepis fraasii-Abies cephalonica comm.

- Sub-community: with Castanea sativa

- Sub-community: with Trifolium grandiflorum

2. Community: Sanicula europaea-Abies cephalonica comm.

- Sub-community: with Silene multicaulis ssp.multicaulis

- Sub-community: with Rubus hirtus

\section{Synecology of the Greek fir forests}

The spatial scale of the analysis should be taken into consideration for any ecological interpretation. Indeed, it is important to distinguish the environmental factors with relevance only at particular scales of analysis from other variables showing an explanatory power across all scales of analysis (Whittaker et al. 2001). In this study, two spatial scales should be considered for the investigated area: the local and the micro-scale.

At the local scale, the floristic differentiation of Greek fir forest communities depends largely on climate. Elevation was the main factor affecting the regional climatic water balance, thus determining the patterns of floristic composition within the Greek fir forest. Elevation does not have any direct ecological or physiological impact on species (Pausas \& Austin 2001), but it is highly correlated with precipitation and air temperature The increase in precipitation and the decrease in temperature with increasing elevation lead to a strong drought gradient. This gradient can be better expressed by the combination of the most important climatic parameters (P, T and PETref) in the Humidity In$\operatorname{dex}(\mathrm{HI})$.

The HI and other related moisture indexes have been repeatedly used to express the climatic water balance and explain the vegetation distribution ranging from regional $(\mathrm{Ma}-$ ther \& Yoshioka 1968, Gärtner et al. 2008) to global scales (Box 1981, Woodward \& Williams 1987). Our results confirm the suitability of HI for describing the climatic water balance of the Greek fir forests at a local scale, as well as the vegetation gradients and thresholds between Greek fir forest communities.

A principal differentiation of the Greek fir forest vegetation into mesophytic and xerophytic plant communities could be found in our study area. Bergmeier (2002) found the same pattern and suggested that water supply was the crucial factor driving the floristic variation of coniferous forests and woodlands of Abies cephalonica, Pinus nigra and Juniperus drupacea on Mt. Parnon (southern Greece). Our results confirm the hypothesis that drought affects the floristic composition of the Greek fir forests in central Greece, determining the occurrence of mesophytic and xerophytic plant communities. Patterns of vegetation differentiation along a gradient of increasing drought are likely common in most Greek fir forests of Greece, as they cover a wide elevational range (Dimopoulos et al. 1996, Bergmeier 2002, Karetsos 2002, Dimitrellos 2005, Vlachos 2006).

At the micro-scale, the floristic differentiation depends on micro-environmental interactions (micro-climate and soil conditions), since the local water balance is further affected by site-specific variations in topography (exposition, inclination) and available soil water storage capacity (ASWSC). The division of the two main Abies forest types in the study area into sub-communities reflects the occurrence of such micro-climatic conditions. Other abiotic parameters (geology, nutrients) as well as biotic interactions (logging, grazing) could also have a significant impact on vegetation. For example, the detected difference in litter accumulation between the two sub-communities of the Sanicula europaea-A. cephalonica community may suggest a nutrient gradient. A similar gradient, from nutrient-rich to nutrient-poor sites, was found on Mt. Parnon (Bergmeier 2002). For a better understanding of these complex relationships, more micro-scale studies in the Greek fir forests are needed, including a more detailed assessment of soil characteristics and, whenever possible, historic land use records and management plans.

Although historic records can be very difficult to find and interpret, such information would help to clarify the interactions of drought with grazing, logging and fire and their subsequent impact on vegetation patterns. The differences in the tree layer cover between the two sub-communities A1 and A2 of the Crepis fraasii-Abies cephalonica community might be the result of such anthropogenic disturbances. Indeed, the presence of Juniperus oxycedrus (prickly juniper) in the shrub layer of such community indicates site degradation due to anthropogenic activities. Wildfires are common in the thermo- and meso-mediterranean zones, sometimes reaching the lower part of the fir forest zone (Koutsias et al. 2012, Xystrakis \& Koutsias 2013). Grazing by sheep and goats is a common practice in the study area. It has been reported that forest fires, overgrazing and illegal logging can lead to degradation and the replacement of forests by prickly juniper shrublands. Where such disturbances have stopped, the degraded land can recover to support a forest with a juniper understory (Theodoropoulos \& Eleftheriadou 2002).

\section{Conclusions}

The floristic variation within the Greek fir forest vegetation of the study area reflects a principal differentiation between mesophytic and xerophytic forest communities. This pattern, mainly driven by climatic factors related to elevation, appears on a local scale. On the Oxia-North Vardousia mountain system the wide altitudinal distribution of Greek fir follows a drought gradient influenced by an increase in precipitation and a decrease in potential evapotranspiration. Greek fir follows a similar elevation gradient in all mountains of southern and central Greece. This suggests that the pattern from mesophytic to xerophytic plant communities is likely typical of all Greek fir forests.

The modified Transeau's humidity index calculated over the driest season appears to be the most suitable variable for the quantification of drought and the climatic water balance on a local scale in central Greece. It is also suitable to delineate the distribution threshold between the mesophytic and xerophytic Greek fir forest communities and to predict their occurrence.

\section{Acknowledgments}

The field work was partly funded by the Deutscher Akademischer Austausch Dienst (DAAD) through the IKYDA-programm. We are grateful to Bernd Künemund, Rodrigo Vargas, Cristabel Durán, Osvaldo Vidal and Carl Höcke for their help in the field. Special thanks go to Nikos Alexandris for helping with the climatic analysis, to Günter Gottschlich for verifying or identifying the specimens of the genus Hieracium, to Michael Lüth for the identification of the mosses, to Christina Petschke for her guidance and help during the soil analysis and to Bernhard Thiel for improving the English of the manuscript. We would also like to thank two anonymous reviewers for their useful comments and recommendations.

\section{References}

Abtew W (1996). Evapotranspiration measurements and modeling for three wetland systems in south Florida. Journal of the American Water Resources Association 32: 465-473. - doi: 10.11 11/j.1752-1688.1996.tb04044.x

Albanis K, Galanos F, Boskos L (2000). Criteria and indicators for the sustainable forest management in Greece. Ministry of Agriculture, General Secretariat of Forests and Natural Environment, Athens, Greece, pp. 101.

Aussenac G (2002). Ecology and ecophysiology of circum-Mediterranean firs in the context of climate change. Annals of Forest Science 59: 823-832. - doi: 10.1051/forest:2002080

Barbéro M, Quézel P (1976). Les groupements forestiers de Grèce Centro-Méridionale [The forest communities in southern and central Greece]. Ecologia Mediterranea 2: 3-86. [in French] doi: 10.3406/medit.1976.1673

Baumann H, Künkele S, Lorenz R (2006). Orchideen Europas mit angrenzenden Gebieten 
[Orchids of Europe and nearby areas]. Eugen Ulmer, Stuttgart, Germany, pp. 333. [in German]

Bergmeier E, Dimopoulos P (2001). Fagus sylvatica forest vegetation in Greece: syntaxonomy and gradient analysis. Journal of Vegetation Science 12:109-126. - doi: 10.1111/j.1654-1103.20 01.tb02622.x

Bergmeier E, Dimopoulos P (2008). Identifying plant communities of thermophilous deciduous forest in Greece: species composition, distribution, ecology and syntaxonomy. Plant Biosystems 142: 228-254. - doi: 10.1080/11263500802 150357

Bergmeier E (2002). Plant communities and habitat differentiation in the Mediterranean coniferous woodlands of Mt. Parnon (Greece). Folia Geobotanica 37: 309-331. - doi: 10.1007/BF028 05214

Blasi C, Di Pietro R, Filesi L (2004). Syntaxonomical revision of Quercetalia pubescenti-petraeae in the Italian Peninsula. Fitosociologia 41: 87-164. [online] URL: http://www.scienzadella vegetazione.it/sisv/documenti/Articolo/pdf/164.p df

Box EO (1981). Predicting physiognomic vegetation types with climate variables. Vegetatio 45:127-139. - doi: 10.1007/BF00119222

Bray JR, Curtis JT (1957). An ordination of the upland forest communities of southern Wisconsin. Ecological monographs 27:325-349. - doi: $10.2307 / 1942268$

Breiman L, Friedman JH, Olshen RA, Stone CJ (1984). Classification and regression trees. Wadsworth International Group, Belmont, CA, USA, pp. 376

Bruelheide H (2000). A new measure of fidelity and its application to defining species groups. Journal of Vegetation Science 11: 167-178. doi: $10.2307 / 3236796$

Brullo S, Giusso del Galdo G, Guarino R (2001). The orophilous communities of the Pino- $\mathrm{Ju}$ niperetea class in the Central and Eastern $\mathrm{Me}-$ diterranean area. Feddes Repertorium 112: 261308. - doi: 10.1002/fedr.20011120308

Böhling N, Greuter W, Raus T (2002). Indicator values of the vascular plants in the Southern Aegean (Greece). Braun-Blanquetia 32: 1-108 [in German with English summary]

Christensen KI (1997). Abies Miller. In: "Flora Hellenica" (Strid A, Tan K eds). Koeltz Scientific Books, Königstein, Germany, pp. 1-3.

Clarke KR (1993). Non-parametric multivariate analyses of changes in community structure. Australian Journal of Ecology 18:117-143. - doi: 10.1111/j.1442-9993.1993.tb00438.x

Dane JH, Hopmans JW (2002). Water retention and storage. Laboratory. In: "Methods of soil analysis. Part 4. Physical methods" (Dane JH, Topp GC eds). Soil Science Society of America, Madison, WI, USA, pp. 675-720.

De Cáceres M, Jansen F (2010). Indicspecies: functions to assess the strength and significance of relationship of species site group associations. $\mathrm{R}$ package version 1.5.1. [online] URL: http:// CRAN.R-project.org/package $=$ indicspecies

De Cáceres M, Legendre P (2009). Associations between species and groups of sites: indices and statistical inference. Ecology 90: 3566-3574. doi: 10.1890/08-1823.1

De Cáceres M, Legendre P, Moretti M (2010). Improving indicator species analysis by combining groups of sites. Oikos 119: 1674-1684. - doi: 10.1111/j.1600-0706.2010.18334.x

Dimitrellos GN (2005). Geobotanical research of Timfristos Mt. (NW Sterea Ellas): flora-vegetation-evaluation-management. PhD Thesis, University of Patras, Patra, Greece, pp. 313. [in Greek with English summary]

Dimopoulos P, Georgiadis T, Sykora K (1996). Phytosociological research on the montane coniferous forests of Greece: Mount Killini (NE Peloponnisos -S Greece). Folia Geobotanica and Phytotaxonomica 31: 169-195. - doi: 10.1007/BF02 812061

Drouzas AD (2000). Determination and analysis variation of Greek fir populations using biochemical and molecular markers. PhD Thesis, Aristotle University of Thessaloniki, Thessaloniki, Greece, pp. 132. [in Greek with English summary]

Ellenberg H, Leuschner C (2010). Vegetation Mitteleuropas mit den Alpen in ökologischer, dynamischer und historischer Sicht [Vegetation of central Europe and the Alps from an ecological, dynamic and historic viewpoint] ( $6^{\text {th }}$ edn). Ulmer UTB, Stuttgart, Germany, pp. 1334. [in German] Euro+Med (2006). Euro+Med Plantbase - the information resource for Euro-Mediterranean plant diversity. [online] URL: http://ww2.bgbm.org/ EuroPlusMed/

Fady B, Conkle MT (1993). Allozyme variation and possible phylogenetic implications in Abies cephalonica Loudon and some related eastern Mediterranean firs. Silvae Genetica 42: 351-359. [online] URL: http://www.sauerlaender-verlag.com/fileadmin/content/dokument/archiv/silvaegenetica/42_1993/42-6-351.pdf

Frank D, Inouyei R (1994). Temporal variation in actual evapotranspiration of terrestrial ecosystems - Patterns and ecological implications. Journal of Biogeography 21: 401-411. - doi: 10.230 7/2845758

Gouvas M, Sakellariou N (2011). Climate and forest vegetation of Greece. National Observatory of Athens, Institute of Environmental Research and Sustainable Development, Athens, Greece, pp. 238. [in Greek with English summary]

Gouvas M, Theodoropoulos K (2014). The influence of air temperature on the lower- and higheraltitudinal distribution limits of forest trees and shrubs in Greece. Forest Research-New Series 22 [in press] [in Greek with English summary].

GRASS Development Team (2010). Geographic Resources Analysis Support System (GRASS GIS) Software. Open Source Geospatial Foundation, USA. Version 6.4.0 [online] URL: http:// grass.osgeo.org

Greuter W, Burdet HM, Long G (1984). Medchecklist (vols 1, 3, 4). Conservatoire et Jardin botaniques de la Ville de Genève, Genève, Switzerland, pp. 853.

Guarino R, Domina G, Pignatti S (2012). Ellen- berg's indicator values for the Flora of Italy first update: Pteridophyta, Gymnospermae and Monocotyledoneae. Flora Mediterranea 22: $197-$ 209. - doi: 10.7320/FIMedit22.197

Gärtner S, Reif A, Xystrakis F, Sayer U, Bendagha N, Matzarakis A (2008). The drought tolerance limit of Fagus sylvatica forest on limestone in southwestern Germany. Journal of Vegetation Science 19:757-768. - doi: 10.3170/20088-18442

Hengl T (2007). A practical guide to geostatistical mapping of environmental variables. JRC Scientific and Technical Reports, European Commission-Joint Research Centre-Institute for Environment and Sustainability, Luxembourg, pp 143. [online] URL: http://www.lu.lv/materiali/biblio teka/es/pilnieteksti/vide/

Hennekens SM, Schaminée JH. (2001). TURBOVEG, a comprehensive data base management system for vegetation data. Journal of Vegetation Science 12:589-591. - doi: 10.2307/3237010

Hill MO, Bell N, Bruggeman-Nannenga MA, Brugués M, Cano MJ, Enroth J, Flatberg KI, Frahm J-P, Gallego MT, Garilleti R, Guerra J, Hedenäs L, Holyoak DT, Hyvönen, Ignatov MS, Lara F, Mazimpaka V, Muñoz J, Söderström L (2006). An annotated checklist of the mosses of Europe and Macaronesia. Journal of Bryology 28:198-267. - doi: 10.1179/174328206X119998 Hofierka J, Šúri M (2002). The solar radiation model for Open source GIS: implementation and applications. In: Proceedings of the "Open source GIS-GRASS users conference 2002" (Ciolli M, Zatelli P eds). Trento (Italy) 11-13 Sep 2002. Department of Civil and Environmental Engineering, University of Trento, Trento, Italy, pp. $1-19$.

Horvat I, Glavac V, Ellenberg H (1974). Vegetation Südosteuropas [Vegetation of southern Europe]. G. Fischer, Stuttgart, Germany, pp. 768. [in German]

Hothorn T, Hornik K, Zeileis A (2006). Unbiased recursive partitioning: a conditional inference framework. Journal of Computational and Graphical Statistics 17: 492-514. - doi: 10.1198/ 106186006X133933

Hothorn T, Hornik K, Zeileis A (2011). Party: a laboratory for recursive partytioning. R package version 0.9-99992. [online] URL: http://CRAN. R-project.org/package= party

Jahn R, Schönfelder P (1995). Exkursionsflora für Kreta [Field-guide Flora of Crete]. Eugen Ulmer, Stuttgart, Germany, pp. 446. [in German]

Kallergis GA, Koch KE, Nikolaus HJ (1970). Geological map of Greece. Institute for Geology and Subsurface Research, Athens, Greece, pp. 1. Karetsos G (2002). Study of the ecology and vegetation of Mt. Iti. PhD Thesis, University of Patras, Patra, Greece, pp. 295. [in Greek with English summary]

Kenkel NC, Orloci L (1986). Applying metric and nonmetric multidimensional scaling to ecological studies: some new results. Ecology 67: 919-928. - doi: $10.2307 / 1939814$

Knapp R (1964). Die Vegetation von Kephallinia, Griechenland. Geobotanische Untersuchung ei- 
nes Mediterranen gebietes und einige ihrer Anwendungsmöglichkeiten in Wirtschaft und Landesplanung [The vegetation of Kefallinia, Greece. Geobotanical studies of a Mediterranean area and some of its application options in economy and landscape planning]. Geobotanische Mitteilungen 29, Geobotanisches Institut, Giessen, Germany, pp. 206. [in German]

Kokmotos E (2008). Floristic and phytosociological research of Boeotia Mountains (Elikon-Xerovouni-Neraidolakomma). Comparative exploration and ecological approach. $\mathrm{PhD}$ Thesis, University of Patras, Patra, Greece, pp. 509. [in Greek with English summary]

Koutsias N, Arianoutsou M, Kallimanis AS, Mallinis G, Halley JM, Dimopoulos P (2012). Where did the fires burn in Peloponnisos, Greece the summer of 2007? Evidence for a synergy of fuel and weather. Agricultural and Forest Meteorology 156: 41-53. - doi: 10.1016/j.agrformet.201 1.12 .006

Kruskal JB (1964a). Multidimensional scaling by optimizing goodness of fit to a nonmetric hypothesis. Psychometrika 29: 1-27. - doi: 10.1007 /BF02289565

Kruskal JB (1964b). Nonmetric multidimensional scaling: a numerical method. Psychometrika 29. 115-129. - doi: 10.1007/BF02289694

Künemund B (2008). Morphologische Variabilität des griechischen Tannenhybriden Abies $\times$ borisii-regis (Mattfeld) [Morphological variability of the Greek fir hybrid Abies $\times$ borisii-regis (Mattfeld)]. Diploma thesis, Albert- Ludwigs Universität, Freiburg im Breisgau, Germany, pp. 73. [in German]

Lance GN, Williams WT (1967). A general theory of classificatory sorting strategies: 1. Hierarchical systems. The Computer Journal 9: 373-380. doi: 10.1093/comjnl/9.4.373

Leyer I, Wesche K (2007). Multivariate Statistik in der Ökologie [Multivariate statistics in ecology]. Springer-Verlag, Berlin Heidelberg, Germany, pp. 37-45. [in German]

Maechler M (2010). Cluster: cluster analysis extended Rousseeuw et al. $\mathrm{R}$ package version 1.13.2 [online] URL: http://CRAN.R-project.org/ package $=$ cluster

Maroulis G (2003). Flora and vegetation of mount Erymanthos ecosystems (NW Peloponnisos). PhD Thesis, University of Patras, Patra, Greece, pp. 405. [in Greek with English summary]

Mather JR, Yoshioka GA (1968). The role of climate in the distribution of vegetation. Annals of the Association of American Geographers 58:29 41. - doi: 10.1111/j.1467-8306.1968.tb01634.x McCune B, Grace J (2002). Analysis of ecological communities. MjM Software Design, Gleneden Beach, Oregon, USA, pp. 300. [online] URL: http://tocs.ulb.tu-darmstadt.de/106964135.pdf McCune B, Keon D (2002). Equations for potential annual direct incident radiation and heat load. Journal of Vegetation Science 13:603-606. - doi: 10.1111/j.1654-1103.2002.tb02087.x Minchin PR (1987). An evaluation of the relative robustness of techniques for ecological ordination. Vegetatio 69: 89-107. - doi: 10.1007/BF00
038690

Mintz Y, Serafini YV (1992). A global monthly climatology of soil moisture and water balance. Climate Dynamics 8: 13-27. - doi: 10.1007/BF0 0209340

Mitsopoulos DJ, Panetsos CP (1987). Origin of variation in fir forests of Greece. Silvae Genetica 36: $1-15$.

Mucina L (1997). Conspectus of classes of European vegetation. Folia Geobotanica 32:117-172. - doi: 10.1007/BF02803738

Oksanen J, Blanchet FG, Kindt R, Legendre P, O'Hara RB, Simpson GL, Solymos P, Stevens MHH, Wagner H (2011). Vegan: community ecology package. $\mathrm{R}$ package version 1.17-10 [online] URL: http://CRAN.R-project.org/packa ge= vegan

Ozenda P (1975). Vegetation levels of the Mediterranean basin mountains. Documents de cartographie écologique 16: 1-32. [in French with English summary]

Palmer WC (1965). Meteorological drought. Research paper 45, US Department of Commerce, Weather Bureau, Washington, DC, USA, pp. 68. Pausas JG, Austin MP (2001). Patterns of plant species richness in relation to different environments: an appraisal. Journal of Vegetation Science 12:153-166. - doi: 10.2307/3236601

Pignatti S, Menegoni P, Pietrosanti S (2005). Valori di bioindicazione delle piantevascolari della Flora d'Italia [Bioindicator values of vascular plants of the Flora of Italy]. Braun-Blanquetia 39: 1-97. [in Italian]

Quézel P, Barbéro M (1985). Carte de la végétation potentielle de la région Méditerranéenne. Feuille no. 1: Méditerranée orientale [Map of potential vegetation of the Mediterranean region. No. 1: Eastern Mediterranean]. CNRS, Paris, France. [in French]

Quézel P (1998). Diversité et répartition des sapins sur le pourtour méditerranéen [Diversity and distribution of firs around the Mediterranean]. Forêt Méditerranéenne 19: 93-104. [in French]

R Core Team (2011). R: a language and environment for statistical computing (version 2.12.2). R Foundation for Statistical Computing, Vienna, Austria. [online] URL: http://www.R-project.org Roberts DW (2010). Labdsv: ordination and multivariate analysis for ecology. R package version 1.4-1 [online] URL: http://CRAN.R-project.org/ package $=$ labdsv

Rydgren K (1996). Vegetation-environment relationships of old-growth spruce forest vegetation in Østmarka Nature Reserve, SE Norway, and comparison of three ordination methods. Nordic Journal of Botany 16: 421-439. - doi: 10.1111/j. 1756-1051.1996.tb00254.x

Samaras DA (2012). The vegetation of Greek fir (Abies cephalonica Loudon) forests on the OxiaNorth Vardousia mountain system, central Greece, in relation to drought. PhD Thesis, Albert-Ludwigs Universität, Freiburg im Breisgau, Germany, pp. 199.

Samaras D, Theodoropoulos K, Eleftheriadou E (2008). The plant communities of Greek fir forests (Abies cephalonica J.W. Loudon) of Mt.
Goulinas (C. Greece). Forest Research-New Series 21: 63-78. [in Greek with English summary] Samaras DA, Reif A, Theodoropoulos K (2014). Evaluation of radiation-based reference evapotranspiration models under different Mediterranean climates in central Greece. Water Resources Management 28: 207-225. - doi: 10.100 7/s11269-013-0480-3

Sayer U (2000). Die Ökologie der Flaumeiche (Quercus pubescens Willd.) und ihrer Hybriden auf Kalkstandorten an ihrer nördlichen Arealgrenze (Untersuchungen zu Boden, Klima und Vegetation) [The ecology of downy oak (Quercus pubescens Willd.) and its hybrids on limestone at its northern distribution limit]. Dissertationes Botanicae 340, Cramer, Stuttgart, Germany, pp. 198. [in German]

Scaltsoyiannes A, Tsaktsira M, Drouzas AD (1999). Allozyme differentiation in the Mediterranean firs (Abies, Pinaceae). A first comparative study with phylogenetic implications. Plant Systematics and Evolution 216: 289-307. - doi: 10.1007/BF01084404

Schütt P (1994). Tannenarten Europas und Kleinasiens [Fir species of Europe and Asia Minor]. Ecomed, Landsberg am Lech, Germany, pp. 132. [in German]

Stephenson NL (1990). Climatic control of vegetation distribution: the role of the water balance. The American Naturalist 135: 649-670. - doi: 10.1086/285067

Stephenson NL (1998). Actual evapotranspiration and deficit: biologically meaningful correlates of vegetation distribution across spatial scales. Journal of Biogeography 25: 855-870. - doi: 10.1046/j.1365-2699.1998.00233.x

Strid A (1986). Mountain flora of Greece, Vol. 1. Cambridge University Press, Cambridge, UK, pp. 822.

Strid A, Tan K (1991). Mountain flora of Greece, vol. 2. Edinburgh University Press, Edinburgh, UK, pp. 974.

Strid A, Tan K (1997). Flora hellenica, vol. 1. Koeltz Scientific Books, Königstein, Germany, pp. 545.

Strid A, Tan K (2002). Flora hellenica, vol. 2. Gantner Verlag, Ruggell, Liechtenstein, pp. 511.

Theodoropoulos K, Eleftheriadou E (2002). The vegetation of prickly Juniper (Juniperus oxycedrus L. ssp. oxycedrus) shrublands on Mount Orvilos (E. Macedonia, Nomos Dramas, Greece). In: Proceedings of the " 3 rd panhellenic rangeland conference" (Platis PD, Papachristou TG eds). Karpenisi (Greece) 4-6 Sep 2002. Ministry of Rural Development and Food, Hellenic Range and Pasture Society, Athens, Greece, pp. 223232. [in Greek with English summary]

Thornthwaite CW (1947). Climate and moisture conservation. Annals of the Association of American Geographers 37: 87-100. - doi: 10.108 0/00045604709351946

Tichý L, Chytrý M (2006). Statistical determination of diagnostic species for site groups of unequal size. Journal of Vegetation Science 17: 809-818. - doi: 10.1111/j.1654-1103.2006.tb025 $04 . x$ 
Tsiripidis I, Bergmeier E, Fotiadis G, Dimopoulos $P$ (2009). A new algorithm for the determination of differential taxa. Journal of Vegetation Science 20: 233-240. - doi: 10.1111/j.1654-1103.20 09.05273.x

Tuhkanen S (1980). Climatic parameters and indices in plant geography. Acta Phytogeographica Suecica 67: 1-105.

Tutin TG, Heywood VH, Burges NA, Moore DM, Valentine DH, Walters SM, Webb DA (1980). Flora Europaea, vols 2-5 ( $1^{\text {st }}$ edn $)$. Cambridge University Press, Cambridge, UK, pp. 1766.

Tutin TG, Burges NA, Chater AO, Edmondson JR, Heywood WH, Moore DM, Valentine DH, Walters SM, Webb DA (1993). Flora Europaea, vol. 1 ( $2^{\text {nd }}$ edn). Cambridge University Press, Cambridge, UK, pp. 581.

Van Der Maabel E (1979). Transformation of cover-abundance values in phytosociology and its effects on community similarity. Vegetatio 39 (2): 97-114. - doi: 10.1007/BF00052021

Van Der Maarel E (2005). Vegetation ecology. Blackwell Publishing, Malden, MS, USA, pp. 395. [online] URL: http://books.google.com/ books?id=bY_VpioznAAC

Vlachos A (2006). Flora, vegetation and ecology of Vardousia Mt. PhD Thesis, University of Patras, Patra, Greece, pp. 395. [in Greek with English summary]

Wallén CC (1967). Aridity definitions and their applicability. Geografiska Annaler 49: 367-384. - doi: 10.2307/520903

Weber HE, Moravec J, Theurillat J-P (2000). International code of phytosociological nomenclature ( $3^{\text {rd }}$ edn). Journal of Vegetation Science 11: 739-768. - doi: 10.2307/3236580

Whittaker RJ, Willis KJ, Field R (2001). Scale and species richness: towards a general, hierarchical theory of species diversity. Journal of Biogeography 28: 453-470. - doi: 10.1046/j.1365-26 99.2001.00563.x

Willmott CJ, Rowe CM, Mintz Y (1985). Climatology of the terrestrial seasonal water cycle. International Journal of Climatology 5:589-606. doi: 10.1002/joc.3370050602

Willner W, Tichý L, Chytrý M (2009). Effects of different fidelity measures and contexts on the determination of diagnostic species. Journal of Vegetation Science 20 (1): 130-137. - doi: 10.11 11/j.1654-1103.2009.05390.x

Woodward FI, Williams BG (1987). Climate and plant distribution at global and local scales. Plant
Ecology 69: 189-197. - doi: 10.1007/BF00038 700

Xystrakis F, Koutsias N (2013). Differences of fire activity and their underlying factors among vegetation formations in Greece. iForest 6: 132140. - doi: 10.3832/ifor0837-006

Xystrakis F (2009). The drought tolerance limit of European beech (Fagus sylvatica L.) stands on Mt. Olympus, NC Greece. PhD Thesis, AlbertLudwigs Universität, Freiburg im Breisgau, Germany, pp. 168

Š́ri M, Hofierka J (2004). A new GIS-based solar radiation model and its application to photovoltaic assessments. Transactions in GIS 8: 175 190. - doi: 10.1111/j.1467-9671.2004.00174.x

\section{Supplementary Material}

Appendix 1 - Environmental variables fitted onto the ordination as vectors or factors.

Link: Samaras_1214@suppl001.xls

Appendix 2 - Vegetation table of the Greek fir forest communities.

Link: Samaras_1214@supp1002.xls 